\title{
Drug prices: How do we get to a better place?
}

\author{
Joel Lexchin MSc MD
}

Cite as: CMAJ 2017 June 12;189:E792-3. doi: 10.1503/cmaj.170440

See related article at www.cmaj.ca/lookup/doi/10.1503/cmaj.161481

$\mathbf{E}$ xorbitant prices for specialty drugs - such as the $\$ 500000$ per-patient annual bill for Soliris (eculizumab), a treatment for a rare blood disorder - generate an enormous amount of publicity and dominate attention given to drug spending. ${ }^{1}$ That publicity obscures how much money is spent on drugs that are more commonly used for diseases such as high blood pressure, depression and diabetes - three of the six therapeutic areas that Morgan and colleagues examine in a linked paper on drivers of drug prices in 10 high-income countries. ${ }^{2}$ According to their analysis, Canadian per capita spending in the six therapeutic areas was $\$ 158$, second only to Switzerland's $\$ 171$. Higher Canadian prices accounted for an excess of $\$ 1.7$ billion. What's more, an extra $\$ 600$ million per year is spent on "choice effects"; that is, differences in the average mix of medicines used by Canadians compared with other nationalities.

According to the IMS Health report for 2015, in that year Canada spent $\$ 268$ million on duloxetine for depression, \$211 million on perindopril for hypertension and \$158 million on sitagliptin for type 2 diabetes. ${ }^{5}$ Canada appears to excel only with respect to the proportion of prescriptions dispensed as generic drugs. Still, Canadian generic prices leave much to be desired compared with many other developed countries. ${ }^{6}$

There is a substantial human cost to high drug prices. About 1 in 12 Canadians aged 55 years and older either skip doses or do not fill prescriptions because they cannot afford them. ${ }^{3}$ Higher out-of-pocket costs for those on social assistance and older people mean more visits to physicians and emergency departments and more hospital admissions. ${ }^{4}$ Canada is not doing well when it comes to ensuring that its population has access to prescription medications; we can and must get to a better place.

What accounts for Canada's poor showing? Canada is the only country among those studied that does not have universal pharmaceutical insurance coverage as part of its universal health care coverage package. In addition, Canadian drug prices are set using a mishmash of approaches for brand-name and generic drugs, making price control for individual products difficult. At the federal level, there is the Patented Medicine Prices Review Board (PMPRB), created in 1987, when Canada restricted and later abolished compulsory licensing as a way to rein in drug spending. The PMPRB establishes a maximum price for new

\section{KEY POINTS}

- Drug prices and spending in Canada are higher than almost all other developed countries.

- High prices have a human cost when people do not take medications because they cannot afford them.

- In order to correct the situation, Canada needs a national pharmacare plan that will allow for monopsony buying power.

patented drugs and then limits price increases to the rate of inflation until the patent expires.

The PMPRB, however, is the product of a flawed piece of legislation. As Zhang and colleagues pointed out in a recent CMAJ commentary, the PMPRB compares Canadian prices with those of seven other countries (France, Germany, Italy, Sweden, Switzerland, United Kingdom and the United States); the authors also stated that from " 2005 to 2014, prices of patented drugs in Canada went from being equal or lower than those in five of six European comparator countries to higher than prices in five of six."

Moreover, the seven countries that the PMPRB uses for this comparison are among the most expensive in the Organisation for Economic Co-operation and Development when it comes to drug spending. As new patented drugs come onto market, they are typically accompanied by aggressive promotion and marketing - more than half a billion dollars annually just for journal advertising and visits by sales representatives ${ }^{5}-$ and this alters doctors' prescribing choices. This shift means that the "mix" becomes more expensive, because new drugs are generally much more costly, although rarely more effective, than older ones. ${ }^{8}$

The PMPRB has no control over generic prices; this remains a provincial responsibility. As noted above, Canada does well internationally in terms of the use of generic instead of brand-name drugs, but each province negotiates generic prices on its own. Lately, however, there has been some measure of cooperation. But although lower generic prices would certainly save money, generic sales account for only $22 \%$ of total spending. ${ }^{9}$

The potential for real savings lies in lowering the prices of brand-name drugs. The provincial and federal drug plans have 
made a start at collective bargaining with the pan-Canadian Pharmaceutical Alliance, but the provinces must first decide which drugs to choose for the negotiation process. Given the absence of universal pharmacare, the public sector controls only about $43 \%$ of total drug spending, ${ }^{10}$ which limits its negotiating power.

Zhang and colleagues recognized that the current version of the PMPRB cannot keep drug prices and spending under control. ${ }^{7}$ The answer is not to reform the PMPRB, but to move to a new way of controlling the prices of both patented brand-name and generic drugs. The Federal Minister of Health, Dr. Jane Philpott, acknowledges that Canadian drug prices are too high, ${ }^{11}$ but uses that as an excuse to reject the obvious solution: a national pharmacare system that would cover everyone in the country. As Morgan and colleagues point out, all of their comparator countries have a universal pharmacare system that allows them to exercise monopsony bargaining power with drug companies.

Canada needs universal pharmacare. The exact form of such a system in Canada would need to be negotiated between the federal and provincial and territorial governments. One possible model would introduce a cost-sharing agreement between the various levels of government, under which the federal government agrees to fund part of the cost; in return, the provinces and territories would provide coverage for drugs in a national formulary for all in their jurisdictions. ${ }^{12}$ Government spending on prescription medications would increase under such a system, but there would also be substantial savings, such that the increase in the overall cost to government is estimated at $\$ 1$ billion annually. ${ }^{13}$

\section{References}

1. Grant K. Rare public hearing highlights concerns over explosion of highpriced specialty drugs in Canada. Globe and Mail [Toronto]. 2017 Jan. 15. Available: www.theglobeandmail.com/news/national/rare-public-hearing -highlights-concerns-over-explosion-of-high-priced-specialty-drugs-in-canada /article33630788 (accessed 2017 Jan. 20).

2. Morgan S, Leopold C, Wagner A. Drivers of expenditure on primary care prescription drugs in 10 high-income countries with universal health coverage. CMAJ 2017;189:E794-9.

3. Morgan SG, Lee A. Cost-related non-adherence to prescribed medicines among older adults: a cross-sectional analysis of a survey in 11 developed countries. BMJ Open 2017;7:e014287.

4. Tamblyn R, Laprise R, Hanley JA, et al. Adverse events associated with prescription drug cost-sharing among poor and elderly persons. JAMA 2001;285:421-9.

5. Canadian pharmaceutical industry review 2015. Montréal: imshealth | brogan; 2016. Available: http://imsbrogancapabilities.com/YIR_2015_FINAL (accessed 2016 Oct. 10).

6. Generics 360: generic drugs in Canada, 2014. Ottawa: National Prescription Drug Utilization Information System; 2016.

7. Zhang R, Martin D, Naylor C. Regulator or regulatory shield? The case for reforming Canada's Patented Medicine Prices Review Board. CMAJ 2017;189:E515-6.

8. Lexchin J. How safe and innovative are first-in-class drugs approved by Health Canada: a cohort study. Healthc Policy 2016;12:65-75.

9. Generic medicine versus brand-name drugs. North York (ON): Canadian Generic Pharmaceutical Association; 2016. Available: www.canadiangenerics. ca/get-the-facts/canadian-market-facts/ (accessed 2017 May 19).

10. Prescribed drug spending in Canada, 2016: a focus on public drug programs. Ottawa: Canadian Institute for Health Information; 2016. Available: https:// secure.cihi.ca/free_products/Prescribed Drug Spending in Canada_2016_EN_ web.pdf (accessed 2017 Apr. 11).

11. Full interview with Minister of Health Jane Philpott. CBC News [The Fifth Estate] 2017 Jan. 13. Available: www.cbc.ca/fifth/blog/full-interview-with-minister-of -health-jane-philpott (accessed 2017 Apr. 12).

12. Morgan SG, Gagon M-A, Mintzes B, et al. A better prescription: advice for a national strategy on pharmaceutical policy in Canada. Healthc Policy 2016;12:18-36.

13. Morgan SG, Law M, Daw JR, et al. Estimated cost of universal public coverage of prescription drugs in Canada. CMAJ 2015;187:491-7.
Competing interests: In 2015/16, Joel Lexchin received payment from two nonprofit organizations as a consultant on one project that dealt with indication-based prescribing, and a second on which drugs should be distributed free of charge by general practitioners. In 2015, he received payment from a for-profit organization for participation on a panel that discussed expanding drug insurance in Canada. He is on the Foundation Board of Health Action International.
Affiliations: School of Health Policy and Management, York University; University Health Network, Toronto, Ont.

This article was solicited and has not been peer reviewed.

Correspondence to: Joel Lexchin, jlexchin@yorku.ca 